\title{
UKRAINIAN-CZECH ECONOMIC LINKS: DIPLOMACY, TRADE, AND TOURISM (THE BEGINNING OF THE XXI CENTURY)
}

\author{
Roman Korsak ${ }^{1}$, Vasyl Ilnytskyi², Ivan Hodia ${ }^{3}$
}

\begin{abstract}
The article's purpose is in a complex manner to analyse Ukrainian-Czech economic cooperation throughout 2000-2017, particularly, in the sphere of economic diplomacy, trade, and tourism. The research methods. The methodological base for a systemic research into Ukrainian-Czech economic cooperation consists of general scientific principles and postulates, as also a wide spectrum of methods, which passed into the theory of international relations from philosophy, gnoseology, ontology, axiology, dialectics, logic, history, and other particular sciences. The results. It has been proved that the bilateral cooperation under consideration depended on the Ukrainian-Czech contract-legal base coordination level, which regulated their mutual relations, repayment prospects of Ukraine's "Yamburg debt" to the Czech Republic, the scope of cooperation of each of the countries with the European Union, and level of tourist attraction. The main long-term economic interests of Ukraine in its relations with the Czech Republic were such: the development of an economic dialogue, the realization of the common Ukrainian-Czech economic and investment projects, and cooperation in tourism development. The economically-advisory dialogue between Ukraine and the Czech Republic, according to their bilateral interstate agreements, was carried out by the Ukrainian-Czech Commission on trade and economic cooperation, the Working group on the liberalization of their mutual trade, and by other institutional bodies. The expert consultations about the cooperation in the areas of tourism, power engineering, agriculture, banking, and other social components made up an effective form of economic dialogue. The signed inter-governmental and inter-departmental contract-legal certificates became an effective result of positive economic cooperation. The most active work in this direction was done on the eve and in the first years of Czechia's membership in the European Union. Despite much work done, it did not bring about the possibility to solve problem questions and to eliminate existing barriers in the bilateral trade. After Czechia's joining the $\mathrm{EU}$, the improvement of a trading mode between the two countries rests within the plane of agreements and the development of a necessary contract-legal base with the EU. Conclusion. The bilateral economic cooperation between Ukraine and the Czech Republic has every prospect for further intensification, especially, in the sphere of statistics of the bilateral trade and economic relations, in Ukraine's fulfilment of its commitments provided by "Yamburg agreements", and in the popularizations of Ukraine's positive tourist image.
\end{abstract}

Key words: Ukraine, Czechia, European Union, "Yamburg agreement", trade and economic relations, economic cooperation, tourist cooperation.

JEL Classification: B17, B27, F1, F18, Z3, Z32

\section{Introduction}

It should be primarily noticed that a generalizing research into the economic cooperation of Ukraine and Czechia is important both from the scientific and practical points of view, as it gives chances to estimate the level of their mutual relations and to find out certain drawbacks and possibilities of its development

Corresponding author:

${ }^{1}$ Uzhhorod National University, Ukraine.

E-mail: korsakr@i.ua

ORCID: https://orcid.org/0000-0002-7886-0671

${ }^{2}$ Ivan Franko Drohobych State Pedagogical University, Ukraine.

E-mail: vilnickiy@gmail.com

ORCID: https://orcid.org/0000-0002-4969-052X

${ }^{3}$ Uzhhorod National University, Ukraine.

E-mail: ivan.hodia@uzhnu.edu.ua

ORCID: https://orcid.org/0000-0002-4027-8811 in political, social, and economic spheres. Also, it is necessary to notice that for the Czech Republic Ukraine is the second country (after Russia) in the economic priority. In its turn, Czechia is among Ukraine's five main trading partners among the EU countries. Besides, it should be pointed out that the large-scale relations of Ukraine with Czechia in tourism are important for 
the understanding of processes of the organization of different areas of its economy and give a chance to define the common and different features of the establishment of tourism in both countries.

\section{Research methods}

The methods of researching into the relations between Ukraine and Czechia form a set of techniques and operations by which help some or other concrete activity in certain areas of diplomatic cooperation and, particularly, in trade and tourism development areas is carried out. The methodological base of studying the international relations, and hence, of a systemic research into the Ukrainian-Czech economic cooperation, is grounded on general scientific principles and stipulations, including a wide spectrum of methods transferred into the theory of international relations from philosophy, gnoseology, ontology, axiology, dialectics, logic, history, mathematics, and from practical activity on all fours. In general understanding, the scientific method manifests itself as a systematized set of consecutive steps, which need to be carried out for the achievement of a definite purpose. From the end of the XVIII century to the beginning of the XX century, the idea that every science has its own method of theoretical research holds a dominant position. However, from the second half of the XX century, the condition when each branch of science has at its disposal a whole arsenal of its own methods and, besides, expands the circle of those which it can borrow for the solution of the problems from the adjacent spheres of knowledge. The research methodology is understood as a set of principles, concrete methods and techniques, whereas the methods of scientific knowledge are different ways of analysing a concrete sphere of cognition, in this case of the Ukrainian-Czech cooperation and its compound, specifically, - the trade, economic, and tourist business cooperation at the beginning of the XXI century.

The statement of the considered theme became possible due to the general scientific methods of knowledge, such as: analysis, synthesis, systematicity, generalization, concreteness, historicism, and the dialectic method. In the scientific study, the following methods have been given an advantage: historicalgenetic, historical-diachronic, comparative, of empirical analysis, and other.

\section{Analysis of recent researches and publications}

It should be noticed that a research into the cooperation of the Czech Republic and Ukraine was carried out by $\mathrm{O}$. Tsup in her $\mathrm{Ph}$. $\mathrm{D}$. thesis. In it, the author made a concrete historical analysis of the process of formation and development of the system of modern Czech-Ukrainian interrelations, elucidated the evolution of the mainstreams of the cooperation between the two countries. Furthermore, in the aforementioned dissertation, much attention is paid to a political compound and, due to this, most economic aspects of the bilateral Czech-Ukrainian cooperation are insufficiently revealed (Tsup, 2009).

The system of the foreign economic relations regulation in the Czech Republic has been examined in V. Fedurets's $\mathrm{Ph}$. D. thesis. In it, the author confines himself to an analysis of the formation of a new system of foreign economic relations of the Czech Republic in the process of the realization of the EU association agreement (Fedurets, 2006).

The problems of migration of the population from Ukraine to the European Union, particularly, to the Czech Republic, in which a significantly great Ukrainian diaspora and a large quantity of labour emigrants live, are considered in O. Malynovska's works (Malynovska, 2004).

What concerns the foreign authors, the problems of the eastern policy of the Czech Republic, including one concerning Ukraine, have been studied by V. Votápek (Votápek, 2004) in his article "The Eastern Policy of the Czech Republic in 1993-2004: Successes, Problems, and Prospects" (Votápek, 2004).

Among a number of other publications, which submit analyses of the Czechia's foreign trade policy, it is necessary to name J. Hrích, whose researches present analyses of the Czech-Ukrainian cooperation under the conditions of the world economic crisis (Hřích, 2008, 2009).

M. Kořan in his publications analyses the foreign policy of the Czech Republic (Kořan, 2009, 2010, 2011, 2012, 2014).

Of the Czech scientific editions, which reflect the foreign policy of the Czech Republic, the yearly "Agenda of the Czech Foreign Policy" (2010, 2011, 2012, 2013, 2016, 2017) should be primarily mentioned. In it, articles on the pressing question of the economic cooperation of Czechia with Ukraine are published annually.

Thus, the Czech researchers consider questions concerning a formation of conceptual bases of the Ukrainian-Czech economic cooperation, forecasting and modelling its development. In its turn, the Ukrainian scientists since recently have started studying the problems of the Ukrainian-Czech cooperation mainly in the political sphere, whereas the other spheres of the bilateral cooperation are not yet subjected to a complex generalization.

\section{The article's purpose}

The purpose is to generalize the development of Ukrainian-Czech economic relations. The achievement of this purpose implies the execution of the following tasks: 
- to analyse the bilateral diplomacy (economic dialogue) throughout the specified period;

- to investigate features of the trade and economic cooperation between Ukraine and the Czech Republic on the eve of the Czechia's joining the EU and under the conditions of its membership in it;

- to define the basic directions of the Ukrainian-Czech cooperation in the sphere of tourism.

\section{The economic diplomacy}

It should be noticed that, unlike the bilateral political cooperation, the economic-advisory dialogue between Ukraine and the Czech Republic, since 1996, has been carried out on a constant basis. In accordance with the bilateral interstate agreements, the Ukrainian-Czech Commission concerning the trade and economic cooperation, Working Group concerning the liberalization of the mutual trade, and the mixed Ukrainian-Czech Commission concerning the international automobile transport have been formed. Besides, the bilateral agreements have provided annual expert consultations about the cooperation in the field of atomic engineering and nuclear industry, state regulation and supervision of the safety at the use of nuclear energy, agriculture, banking, in the spheres of certification, state statistics, social maintenance, etc. Annually, over 50 delegations of the Ukrainian ministries, departments, regions, and cities visit Czechia. The initiation and practical coordination of the necessary actions, as well as the efficient coordination of the positions of the parties, have been carried out by the Embassy of Ukraine in the Czech Republic and the Trade-economic mission (Korsak, 2015: 193-194).

Throughout 2000-2003 the bilateral economic relations developed in the course of the preparation of the Czech Republic for the entrance into the EU. A favourable factor then was that the Government of the Czech Republic was consistently realizing its program lines in the sphere of international relations, including the deepening of the all-round contacts with Ukraine. It was at that time that the Minister for Foreign Affairs of Ukraine paid a visit to Czechia (2003) and meetings of the Ukrainian and Czech presidents and prime ministers took place during the international forums (2003) (Korsak, 2003: 87-99).

Of the high officials who made visits to Czechia were the President of Ukraine (2009), the Chairman of the Supreme Rada of Ukraine (2005), the Prime Minister of Ukraine (2006, 2011), the Minister for Foreign Affairs of Ukraine (2007, 2008, 2009), and a chain of other ministers, including those of the economic block. In its turn, Ukraine was visited by the President of Czechia (2005), the Chairman of the Chamber of Parliamentary Deputies of the Czech Republic (2008), the Prime Minister of the Czech Republic $(2007,2008,2009)$, and its Minister for Foreign Affairs (2010) (The Materials for the account on the work of the Ukrainian Embassy in the Czech Republic, 2005: 2-3; The Materials for the account on the work of the Ukrainian Embassy in the Czech Republic, 2006: 3-5; Hřích, 2008: 333; Hřích, 2009: 303-316; Kořan, 2012: 17-28).

After the presidential election of 2010 in Ukraine, a crisis of the diplomatic dialogue between Ukraine and Czechia took place. The litigations of the exofficials brought about criticism from the EU countries, including Czechia. For these reasons, the President of Czechia V. Klaus refused to visit Ukraine in May 2012. The government of the Czech Republic pronounced upon an importance of the establishment of accurate conditions for an agreement of Ukraine's association with the EU as it would have activated trade, economic, and political relations between Ukraine and the Czech Republic at a qualitatively new level (Kořan, 2011: 15-32; Kořan, 2013: 19-33; Agenda pro českou zahranicni politiku 2011, 49).

In the economic sphere, 34 interstate, intergovernmental, and inter-departmental contractlegal statements were signed throughout 2000-2017. The most active work in this field was carried out on the eve and in the first years of Czech membership in the European Union. But even before Czechia's joining the European community, an adaptation of the bilateral contract-legal base to the EU standards had begun. After the entrance of the Czech Republic into the European Union, the agreements defining a trading mode between the two countries became invalid. Since May 1st, 2004, four bilateral agreements were denounced, in particular, about trade and economic relations and scientific and technical cooperation. Czechia, which was interested in an advancement of the export on the Ukrainian market, often took the initiative in the contractual process (The Materials for the account on the work of the Ukrainian Embassy in the Czech Republic, 2004: 8).

It should be specified that the economic cooperation was co-ordinated by the activity of the UkrainianCzech inter-governmental Commission on trade and economic cooperation. After Czechia's acquisition of the membership in the EU, it was reorganized into the inter-governmental Ukrainian-Czech Mixed Commission on economic, industrial, scientific, and technical cooperation. In the period of Czechia's preparation for the entrance in the European Union, the fifth (2000), sixth (2001), seventh (2002), and eighth (2004) sessions of the Ukrainian-Czech intergovernmental Commission on trade and economic cooperation took place, in which the conditions and prospects of trade and economic cooperation between Ukraine and the Czech Republic were considered. In the next two years, no sessions of the Commission were organized, as the new agreement about the economic, industrial, and scientific-technical cooperation, which determined its function, was ratified by the Supreme Council (Verkhovna Rada) of Ukraine only in 2006 (Z 
prava o zahranisni politice Česke republiky za rok 2000: 140-141; Z prava o zahranisni politice Česke republiky za rok 2002: 224-225; Z prava o zahranisni politice Česke republiky za rok 2003: 249-251; Z prava o zahranisni politice Česke republiky za rok 2004: 263-265).

In 2007-2017, seven sessions of the inter-governmental Ukrainian-Czech Mixed Commission on economic, industrial, and scientific-technical cooperation were held. At the latest session (Kyiv, on June 7-8, 2017), pressing questions of the Ukrainian-Czech trade, economic, and investment cooperation were discussed and an expansion of the interaction of the two countries at the regional equal was considered. It is possible to assert that the Ukrainian-Czech Inter-governmental Mixed Commission remains an effective institutional, expert, and regular body in developing the directions of expansion, improvement, and deepening of the bilateral trade and economic relations (On the fourth session of the Ukrainian-Czech Inter-governmental Mixed Commission, 2010; On the session of the UkrainianCzech Inter-governmental Mixed Commission, 2017).

\section{The bilateral trade}

It should be noticed that throughout 2000-2017 the basic areas of the Ukrainian-Czech economic cooperation were such: mechanical engineering, chemical, heavy, light, and food-processing industries, the building complex, transport communications, and tourism. In 2001, Ukraine and Czechia managed to restore the general goods turnover (443.1 million US dollars), which had fallen half owing to the Russian financial crises in 1999 has. During this period, the specified mutual trade was characterized by simple goods exchange operations, considerable debts of the Ukrainian enterprises for the acquired Czech products, the absence of the common projects, and low investment (Korsak, 2003: 87-99).

Since May 1, 2004, when the Czech Republic joined the uniform EU customs space, its trading mode with Ukraine changed, the access conditions of two countries on the markets became unequal, being more rigid for the Ukrainian exporters. Concerning the import of Ukrainian products after the entrance of the Czech Republic into the EU, 8 antidumping measures, introduced by the European Union were put in operation. The unilateral quantitative restrictions from the EU concerning the import of Ukrainian metallurgical production, in particular, rolled metal, had the greatest influence. Already in the first year of Czechia's membership in the EU, the losses of the Ukrainian exporters from these restrictions reached 25-26 million US dollars (Materialy do zvitu pro robotu Posolstva Ukrainy u Cheskii Respublitsi, 2005: 19-22).

The strengthening of the economies of the two countries was accompanied by the dynamic increase of their goods turnover. 2006 was critical for the Ukrainian export (341.6 million US dollars). The crisis level then reached minus indicators in comparison with 2005 ( 377.3 million US dollars) and 2009 (340.686 million US dollars) and - due to the world financial and economic crisis - the goods turnover volumes between the two countries were cut by half. After some increase of export from Ukraine to the Czech Republic in 2010-2011 (626. 246 and 842.432 million US dollars correspondingly), in 2012 its decrease (707.040 million US dollars) took place again. That was an evidence of yet insuperable crisis phenomena in Ukraine's economy. The unequal conditions of the access of two countries on the markets, which for Ukrainian manufacturers was more rigid, low competitive ability, and a considerable raw material compound of Ukrainian export created a great rupture in the trading streams and rates of export increase in favour of Czechia (Z práva o zahranicní politice ČR za rok 2006: 233-234; Z práva o zahranicní politice ČR za rok 2009: 296-299; Z práva o zahranicní politice ČR za rok 2010: 212-213; Agendapro českou zahranicni politiku 2012: 47-48).

Since 2013, the reduction of the volume of Czech import to Ukraine (by 19.8\%) took place and this tendency went on in 2014 (by 31.2\%) and 2015 (by $30.3 \%$ ). In Czech import to Ukraine, goods with large surplus value prevailed, such as reactors, boilers, machines, apparatuses, and mechanical devices $(20.3 \%$ in the structure of Czech total import to Ukraine), electric cars and equipment (16.8\%) (Agenda pro českou zahranicni politiku 2013: 46-47).

According to the data of the State Statistics Service of Ukraine, the goods turnover volume between Ukraine and the Czech Republic during 2016 increased to 1219.709 million US dollar. The volume of the Czech Republic's direct investments into the Ukrainian economy in 2016 reached 129.2 million US dollars, which was $1.2 \%$ more than had been by January 1st, 2016. The State Statistics Service of Ukraine, however, closed the data of the Ukrainian investments into the economy of the Czech Republic. According to the Czech national bank, the volume of Ukrainian investments into the economy of the Czech Republic by 01.01.2016 reached nearly 50.50 million US dollars (Torhovelno-ekonomichne spivrobitnytstvo mizh Ukrainoiu ta ChR; Agenda pro českou zahranicni politiku 2016: 45-47).

It's worthy of note that after a serious recession throughout 2014-2015 the goods turnover between Ukraine and Czechia for the first quarter of 2017 increased by one-third and neared 315 million US dollars, which was by $32 \%$ more in comparison with the similar period of 2016 (Torhovelno-ekonomichne spivrobitnytstvo mizh Ukrainoiu ta ChR; Agendapro českou zahranicni politiku 2017: 33-34).

Ukraine's "Yamburg debt" to the Czech Republic equivalent to 1247 million cubic meters of natural gas had a particular negative influence on Ukrainian-Czech 
interstate cooperation.Accordingtotheinter-governmental agreement, which became valid in 1999, Ukraine admitted its debt for the sum of 79.17 million conventional account units. Among the countries involved in the "Yamburg agreements" (Ukraine, Russia, Kazakhstan), the question of the repayment of the debts was not settled only by Ukraine. Actually, till 2004 the parties conducted a long negotiating process concerning the sources of the repayment. The question of the settling of "Yamburg debt" was raised by the Czech side practically at all the bilateral meetings. The problem's complexity consisted of Ukraine's lack of finances for the repayment of its debt and in the fact that Ukraine had no necessary volume of natural gas of its own extraction. In the researcher's opinion, a uniform way of the solution to this problem is to liquidate the debt not in gas volume but in dollars or other convertible currencies (Korsak, 2015: 235-238).

\section{The cooperation in the sphere of tourism}

As to the cooperation of Ukraine and the Czech Republic in the sphere of tourism, it takes place within the context of the relations of Ukraine, Czechia, and the EU. In particular, the coordination of mutual relations in tourism is carried out by a higher body of executive power of the European Union, that is, by the European Commission, which - through the activity of the structural funds - carries out its work on tourism development in the EU countries. The specified body carries out investments into the tourism industry of the countries of Central and Eastern Europe, to which Czechia and Ukraine belong (Korsak, Furtii, 2016).

It deserves noticing that the economic cooperation of Ukraine and the Czech Republic in tourism realized on the basis of a corresponding agreement between Ukraine's Ministry of Culture and Tourism and Czechia's Ministry of Regional Development on the cooperation in the sphere of tourism from 17.02.2006 and of development programs "Europe - 2020", which purpose is to provide a high level of employment increase in the EU, to create an "innovative union" that would open the door to science and new technologies. It should be underlined that within the borders of the realization of the inter-governmental and inter-departmental cooperation agreements in tourism, the UkrainianCzech inter-departmental working group was created (Korsak, Berets, 2016).

The Ukrainian-Czech bilateral tourist cooperation is carried out also within the functional capacity of the European Tourist Commission (ETC). Furthermore, Ukraine's participation in TACIS, a national program created to support small- and middle-scale enterprises for the purpose of maintaining effective functioning of the tourist infrastructure was one of the directions of its cooperation with the Czech Republic in the sphere of tourism. In particular, the corresponding Program of development of the tourist infrastructure in view with the directions of the national network of international transport corridors and the basic transport highways was adopted (Korsak, Furtii, 2016).

As to the tourist streams, it should be noticed that in the recent years the citizens of Ukraine make up 1\% of the tourist visiting Czechia and take the 15th place in the statistics of the most frequent visitors of the Czech capital. The Ukrainian tourists stay in Czechia, on the average, for 2.7 nights. In addition to this, Ukrainian tourists have taken fourth place in the statistics of the number of nights spent in Prague. Only tourists from Spain (2.8 nights), Italy (2.9 nights), and Russia (3.9 nights) spend in Prague more time than Ukrainians (Kravets V. Hid po Prazi ta Chekhii).

In the aforementioned context, it is necessary for the Ukrainian governments to pay more attention to the development of the cooperation with Czechia in the field of tourism, as it will give a chance to push the domestic tourist services on the European market and to receive an experience of tourist activity of the successful enterprises of the EU countries. Thus, the cooperation of Ukraine with the Czech Republic will raise economic efficiency of the national tourist sphere in the future.

In the author's opinion, the following questions should be settled with Czechia in order to intensify Ukraine-Czech cooperation in tourist area:

- to foster the improvement of quality growth of tourist services;

- to develop systems of standardization and certification of the enterprises of the tourist sphere in Ukraine, which could meet the international standards and norms of the European Union;

- to simplify border crossing and customs formalities in the official registration of documents;

- to carry out investment activity;

- to give technical help from the states of the European Union;

- to create a corresponding system of the preparation of the personnel and increase of its qualification by training it in the countries of the European Union (Korsak, Furtii, 2016).

\section{Conclusions}

So, the basic areas of the Ukrainian-Czech economic cooperation during 2000-2017 were such: mechanical engineering, heavy, chemical, light and foodprocessing industries, the building complex, transport communications, and tourism. After the entrance of the Czech Republic in the European Union, for Ukraine to expand its foreign economic relations with Czechia and to strengthen the positions of its exporters on the Czech market became important. Therefore, the UkrainianCzech trade and economic cooperation had a tendency of strengthening investment-production cooperation between the two countries, deepening industrial cooperation, and creating the common enterprises. 
For the improvement of the specified bilateral economic cooperation, it is necessary for the governmental factors of both countries to settle the following questions:

- in the sphere of statistics of Ukrainian-Czech trade and economic relations, it is necessary to improve the methods of statistical calculations of the bilateral goods turnover and, hence, to advance it to the corresponding technique of the European Union;
- to offer concrete actions from the Ukrainian side on the fulfilment of the commitments set by the "Yamburg agreements";

- to carry out timely calculations and to pay the long-term debts of the Ukrainian enterprises for the production and equipment imported from Czechia; - to liberalize customs formalities with the European countries for an increase of tourist streams;

- to popularize Ukraine's positive tourist image in the European market.

\section{References:}

Tsup, O. V. (2009). Cheska Respublika i Ukraina v mizhderzhavnykh vidnosynakh kintsia XX - pochatku XXI st. [The Czech Republic and Ukraine in interstate relations from the end of the XX century to the beginning of the XXI century]: avtoref. dys. kand. ist. nauk: 07.00.02; Lviv: Lvivskyi natsionalnyi universytet im. I. Franka, 20 p. (in Ukrainian)

Fedurets, V. P. (2006). Systema rehuliuvannia zovnishnoekonomichnykh zviazkiv u Cheskii Respublitsi: dosvid orhanizatsii dlia Ukrainy [A system of regulation of foreign economic relations in the Czech Republic: the organizational experience for Ukraine]: avtoreferat dysertatsii na zdobuttia naukovoho stupenia kandydata ekonomichnykh nauk. Uzhhorod: UzhNU, 20 p. (in Ukrainian)

Malynovska, O. (2004). Ukraina, Yevropa, mihratsiia: mihratsii naselennia Ukrainy v umovakh rozshyrennia YeS [Ukraine, Europe, migration: the migrations of Ukraine's population in the conditions of the EU expansion]. Kyiv: Blank-Pres, 171 p. (in Ukrainian)

Votápek, V. (2004). Ceska vyhodni politika [Czechia's favourable politics] Zahranicni politika Ceske republiky 1993-2004. Uspechy, problemy a perspektivy / [O. Pick, V. Handl (eds.) a kolektiv autoru]. Praha: Ustav mezinarodnich vztahu, pp. 99-108. (in Czech)

Hřích, J. (2008). Hospodařsky rozměr česke zahranični politiky [The economical capacity of Czech foreign policy. The measures against an economic crisis] Analyza UMV Česka zahranični politika v roce 2007 / In: Kořan Michal. Praha: Ustav mezinarodnich vztahů, p. 333. (in Czech)

Hř́ch, J. (2009). Hospodařsky rozmèr česke zahranični politiky. Dưležity nastroj boje s hospodařskou krizi [The economical capacity of Czech foreign policy. The measures against an economic crisis] Ceska zahranični politika v roce 2009. Analyza UMV / In: Kořan Michal. - Praha: Ustav mezinarodnich vztahů, pp. 303-316. (in Czech)

Kořan, M. (2009). Politicky kontext a tvorba česke zahranični politiky v roce 2008 [The political context and formation of Czech foreign policy in the year of 2008] Česka zahranični politika v roce 2008. Analyza UMV / In: Kořan, Michal. Praha: Ustav mezinarodnich vztahů, Praha, pp. 13-40. (in Czech)

Kořan, M. (2010). Politicky kontext a tvorba česke zahranični politiky v roce 2009 [The political context and formation of Czech foreign policy in the year of 2009] Česka zahranični politika v roce 2009. Analyza UMV / In: Kořan Michal (ed). Praha: Ustav mezinarodnich vztahů, Praha, pp. 15-40. (in Czech)

Kořan, M. (2011). Politicky kontext a tvorba česke zahranični politiky v roce 2010 [The political context and formation of Czech foreign policy in the year of 2010] Česka zahranični politika v roce 2010. Analyza UMV / In: Kořan Michal - Praha: Ustav mezinarodnich vztahů, pp. 15-32. (in Czech)

Kořan, M. (2012). Politicky kontext a tvorba česke zahranični politiky v roce 2011 [The political context and formation of Czech foreign policy in the year of 2011] Česka zahranični politika v roce 2011. Analyza UMV / In: Kořan, Michal (ed). Praha: Ustav mezinarodnich vztahů, Praha, p. 17-28. (in Czech)

Kořan, M. (2013). Politicky kontext a tvorba česke zahranični politiky v roce 2012 [The political context and formation of Czech foreign policy in the year of 2012] Česka zahranični politika v roce 2012. Analyza UMV / In: Kořan, Michal (ed). Praha: Ustav mezinarodnich vztahů, Praha, pp. 19-33. (in Czech)

Agenda pro českou zahranicni politiku 2011 (2011). [The structure of Czech foreign policy in 2011] Ed. Vit Dostal, Tomaš Karasek, Michal Thim. Praha: Asociace pro mezinarodni otazky (AMO), 214 p. (in Czech)

Agenda pro českou zahranicni politiku 2012 (2012). [The structure of Czech foreign policy in 2012] Ed. Vit Dostal, Tomaš Karasek, Michal Thim. Praha: Asociace pro mezinarodni otazky (AMO), 216 p. (in Czech)

Agenda pro českou zahranicni politiku 2013 (2013). [The structure of Czech foreign policy in 2013] Ed. Vit Dostal, Jakub Eberle Tomaš Karasek. Praha: Asociace pro mezinarodni otazky (AMO), 68 p. (in Czech)

Agenda pro českou zahranicni politiku 2016 (2016). [The structure of Czech foreign policy in 2016] Ed. Vit Dostal. Praha: Asociace pro mezinarodni otazky (AMO), 84 p. (in Czech)

Agenda pro českou zahranicni politiku 2017 (2017). [The structure of Czech foreign policy in 2017] Ed. Vit Dostal. Praha: Asociace pro mezinarodni otazky (AMO), 80 p. (in Czech)

Korsak, R. V. (2015). Ukrainsko-cheski vidnosyny u transformatsiinykh protsesakh Tsentralno-Skhidnoi Yevropy: torhovelno-ekonomichnyi kontekst spivpratsi (2000-2012) [Ukrainian-Czech relations in the transformational processes of central-east Europe: the trade-economic context of the cooperation (2000-2012)]. Uzhhorod: $\mathrm{PP} \ll$ AUTDOR-ShARK». 340 p. (in Ukrainian) 
Korsak, R. V. (2003). Stan i perspektyvy ukrainsko-cheskoho spivrobitnytstva (kinets XX-poch. XXIst.) [The condition and prospects of Ukrainian-Czech cooperation (end XX - beg. XXI)]. Naukovyi visnyk Uzhhorod. un-tu. Seriia: Istoriia. Uzhhorod: Vydavnytstvo UzhDU, vyp. 9, p. 87-99. (in Ukrainian)

Materialy do zvitu pro robotu Posolstva Ukrainy u Cheskii Respublitsi v chastyni torhovelno-ekonomichnoho spivrobitnytstva za 2005 r. [The Materials for the account on the work of the Ukrainian Embassy in the Czech Republic regarding trade and economic cooperation for 2005]. Potochnyi arkhiv Posolstva Ukrainy v Cheskii Respublitsi. Sprava № 123 vid 19.12.2005 r., 50 p. (in Ukrainian)

Materialy do zvitu pro robotu Posolstva Ukrainy u Cheski Respublitsi za 2006 r. v chastyni torhovelnoekonomichnoho spivrobitnytstva [The Materials for the account on the work of the Ukrainian Embassy in the Czech Republic regarding trade and economic cooperation for 2006]. Potochnyi arkhiv Posolstva Ukrainy v Cheskii Respublitsi. Sprava № 12 / 36 vid 6.07.2006 r., 18 p. (in Ukrainian)

Materialy do zvitu pro robotu Posolstva Ukrainy u Cheskii Respublitsi v chastyni torhovelno-ekonomichnoho spivrobitnytstva za 2004 r. [The Materials for the account on the work of the Ukrainian Embassy in the Czech Republic regarding trade and economic cooperation for 2004]. Potochnyi arkhiv Posolstva Ukrainy v Cheskii Respublitsi. Sprava № 20 vid 20.06.2004 r., 40 p. (in Ukrainian)

Zprava o zahranisni politice Česke republiky za rok 2000. Vztahy se zemémi Strední Evropy (2001). [From the account of the foreign policy of the Czech Republic in 2000. Our gains in Middle Europe]. Ministerstvo zahranicních véci ČR, 278 p. (in Czech)

Zprava o zahranisni politice Česke republiky za rok 2001 (2002). [From the account of the foreign policy of the Czech Republic in 2001]. Ministerstvo zahranicních véci ČR, 301 p. (in Czech)

Zprava o zahranisni politice Česke republiky za rok 2002 (2003). [From the account of the foreign policy of the Czech Republic in 2002]. Ministerstvo zahranicních véci ČR, 344 p. (in Czech)

Zpráva o zahranicní politice ČR za rok 2004 (2005). [From the account of the foreign policy of the Czech Republic in 2004]. Ministerstvo zahranicních véci ČR. Bilaterílní vztahy České republiky, 334 p. (in Czech)

Shchodo chetvertoho zasidannia ukrainsko-cheskoi Zmishanoi Komisii z pytan ekonomichnoho, promyslovoho ta naukovo-tekhnichnoho spivrobitnytstva (23-24 veresnia 2010 r.) [On the fourth session of the UkrainianCzech Mixed Commission on economic, industrial, and scientific-technical cooperation (on September 23-24, 2010)]. Ministerstvo ekonomichnoho rozvytku i torhivli Ukrainy. Retrieved from: http://ukrexport.gov.ua/ukr/ $\mathrm{mk}$ info/? country=cze (in Ukrainian)

Zasidannia Ukrainsko-cheskoi mizhuriadovoi zmishanoi komisii z ekonomichnoho, promyslovoho ta naukovotekhnichnoho spivrobitnytstva (7-8 chervnia 2017 r.) [The session of the Ukrainian-Czech Mixed Intergovernmental Commission on economic, industrial, and scientific-technical cooperation (on June 7-8, 2017)]. Ministerstvo zakordonnykh sprav Ukrainy. Retrieved from: http://mfa.gov.ua/ua/press-center/news/57661zasidannya-ukrajinsyko-chesykoji-mizhuryadovoji-zmishanoji-komisiji-z-jekonomichnogo-promislovogo-tanaukovo-tehnichnogo-spivrobitnictva (in Ukrainian)

Zpráva o zahranicní politice ČR za rok 2006 (2007). [From the account of the foreign policy of the Czech Republic in 2006]. MZV ČR. Bilaterílní vztahy České republiky, 474 p. (in Czech)

Zpráva o zahranicní politice ČR za rok 2009 (2010). [From the account of the foreign policy of the Czech Republic in 2009]. MZV ČR. Bilaterílní vztahy České republiky, 610 p. (in Czech)

Zpráva o zahranicní politice ČR za rok 2010 (2011). [From the account of the foreign policy of the Czech Republic in 2010] MZV ČR. Bilaterílní vztahy České republiky, 397 p. (in Czech)

Torhovelno-ekonomichne spivrobitnytstvo mizh Ukrainoiu ta ChR. Informatsiina dovidka [The trade and economic cooperation between Ukraine and the Czech Republic. The information reference]. Posolstvo Ukrainy v ChR. Retrieved from: http://czechia.mfa.gov.ua/ua/about-ukraine/european-integration/ukraine-eu-trade (in Ukrainian)

Korsak, R., Furtii, V. (2016). Ukraina-YeS: spivrobitnytstvo u sferi turyzmu (poch. XXI st.) [Ukraine - Europe: the cooperation in the sphere of tourism (in the beginning of the XXI century)] Hileia: naukovyi visnyk. Zbirnyk naukovykh prats. Hol. red. V. M. Vashkevych. Kyiv: «Vydavnytstvo «Hileia», vyp. 109(6), pp. 99-103. (in Ukrainian)

Korsak, R., Berets, A. (2016). Rozvytok turyzmu v krainakh Yevropeiskoho Soiuzu ta dosvid orhanizatsii dlia Ukrainy na pochatku XXI st. [Tourism development in the countries of the European Union and the organizational experience for Ukraine in the beginning of the XXI century] Hileia: naukovyi visnyk. Zbirnyk naukovykh prats. Kyiv: «Vydavnytstvo «Hileia», vyp. 108(5), pp. 96-100. (in Ukrainian)

Kravets, V. Hid po Prazi ta Chekhii [Kravets V. A guidebook of Prague and Czechia]. Retrieved from: https://uk-ua.facebook.com/praha.guide.info/posts/ (in Ukrainian) 